\title{
Lifestyle, Motivation, and Purchase Intention of Luxury Bag With Instagram Facility as Moderation on Millennial Generation
}

\author{
Hatane Semuel ${ }^{1}$, Fabiola Sampurno ${ }^{2}$ \\ \{samy@petra.ac.id ${ }^{1}$; fabiolasampurno@gmail.com ${ }^{2}$ \} \\ Petra University, Surabaya, Indonesia ${ }^{1,2}$
}

\begin{abstract}
The advances in information technology have led to interesting phenomena, such as the increasing number of luxury goods that can be marketed through social media such as Instagram, which is mostly used by millennials. This generation has unique characteristics in shopping compared to previous generations. This study aims to determine the effect of lifestyle and motivation on the interest in buying millennial generation branded handbags with Instagram facilities as moderation. The research data was obtained through questionnaire distribution with the help of google forms for 165 respondents online and analyzed using PLS software. The results showed that lifestyle and motivation had a significant influence on purchase intentions, while the Instagram facility had no significant effect on shopping intentions. It also shows that the Instagram facility does not moderate the influence of lifestyle and purchase intentions or motivation and purchase intentions.
\end{abstract}

Keywords: Lifestyle, Utilitarian Motivation, Hedonic Motivation, Instagram Facility, and Purchase Intention.

\section{Introduction}

These days, there have been a lot of interesting phenomena related to technology advances. The latest trend is the online character information and telecommunication technology, that is, through the internet. The most online activity that today's Indonesian society love is "ERetailing". Electronic Retailing is a process of selling or buying a product or service through the internet. According to data from APJII (The Indonesian Association of Internet Service Providers), it is clear that $11 \%$ of internet users in Indonesia access the internet only for shopping online. One of the top examples is shopping through Instagram.

Instagram is used not only to share photos or videos but also to become a business media. The term "Instagram Online Shop" is not new among Indonesian people. There are sellers who finally run their businesses online because they feel that this way is a lot easier, especially because Instagram has facilities that support buying and selling processes, such as, like, comment, share, tags, hashtags, Instagram Story, Instagram TV, and so on [1].

Besides the internet-based product purchase phenomenon, from a total of $100 \%$ internet users in Indonesia, 49\% are productive aged people and categorized in the millennial generation [2]. A millennial generation is a group of people who were born at the beginning of 1980 until 2000 and are hence 18 to 35 years old in 2019. This generation can be said as young, active, energetic, open-minded, and very close to telecommunication technology, that 
is, the internet [3]. The generation which dominates the business market has a tendency to buy products that can increase their self-worth in order to show off wealth and purchasing power to one another. They usually buy fashion and luxury goods, including branded bags [4].

\section{Theoretical Review}

\subsection{E-Retailing}

E-Retailing is defined as a retail activity (the selling of products or services) done through the internet (online). Different from e-commerce, e-retailing only involves B2C (business to consumers), where a business sells products or services to consumers directly. It can be concluded that e-commerce is a big domain in doing business through the internet, and eretailing is a part of it [5].

\subsection{Social Media (Instagram)}

Social media can be defined as a group of internet-based applications that builds technology from Web 2.0, which allows users to create and share information (sharing in the sense of socializing) [6]. Examples of social media that are mostly used in Indonesia are Facebook, Youtube, Instagram, Twitter, Pinterest, dan Google+.

Instagram comes from the words "instan" and "telegram". "Insta" or "instan" refers to polaroid photos some years back, which could create photos instantly. On the other hand, the word "gram" means telegram, which means sending information from one party to another fast. Instagram, as a whole, means an application where someone can take, process, and edit photos before sharing them with others [7]. In this modern era, Instagram users no longer use Instagram as an ordinary networking media but as a means to expand their businesses. Instagram becomes a media as well as technology to market products or services of companies [8]. Selling and marketing products in Instagram is seen as very beneficial because Instagram application always has a lot of facilities (features) which attract and support business process, which can be done on Instagram. The facilities include : Instagram Business[9],[10].

\section{Follow}

Instagram, as social media surely has a feature to increase the number of connections. Therefore, this follows feature helps someone to follow or befriend other users.

2. Like

Instagram users can also give like by clicking a heart button at every posted video or photo or simply double-tapping the photo or video.

3. Comments

The comment button is also provided for every user who wants to comment on a photo or a video posted by other users. The comments may be praises, suggestions, and criticisms.

4. Mentions

This feature is useful to summon other users by adding the arroba sign (@), followed by the names of the users that want to be mentioned.

5. Hashtag

In the Instagram application, a hashtag is shown with the \# sign. This feature can be used to collect data or information so that users can find whatever is in trend now more easily from their personal accounts. 
6. Instagram Stories

Instagram users can upload 20-second videos to show their daily activities or something interesting to Instagram Stories. In the business world of Instagram, content creators can make use of the Instagram Storie's facility to advertise the products they sell.

7. Instagram TV

Instagram TV facility can give comfort to all content creators when explaining the products they sell. Different from Instagram Story, one video uploaded on Instagram TV can be up to an hour-long.

\subsection{Branded Bags}

Bags are one of the many important things for some men and women. Bags function not only as carriers of needed items but also as personality representatives of the owners. A large number of bag lovers have caused large varieties of prices and types of this item. The users also vary from low to middle classes and from the middle to premium user classes [11].

In the $21^{\text {st }}$ century, consumers of luxurious items, especially branded bags, flourish among young people. There are a lot of branded bag users coming from the millennial generation, that is, those aged between 18 and 35. Millennial consumers consider that having branded bags is a lifestyle and an investment. Investments in branded bags that have designer labels or famous brands can be a benefit in the future [12]. Some of the favorite branded bags among the millennials are LV, Prada, Chanel, Gucci, Dior, and so on.

\subsection{The Millennial Generation}

The millennial generation, which is normally known as generation $\mathrm{Y}$, is a generation that was born in early 1980 until early 2000. In 2018, this generation was between 18 to 35 years old.

This generation was born in a modernized world, and the use of technology has been very advanced. The closeness to technology is shown through the use and knowledge of the internet (social media), computers, cell phones, video games, music, and others. According to a researcher named Stephanie Noble and her partners in the business journal they wrote, there are at least five characteristics owned by the millennial generation [13]:

a) An active and independent generation

b) A generation with a high rate of self-confidence and ambitions in reaching a goal

c) A generation which tends to maximize the use of technology, particularly social media (active internet users) to socialize

d) A generation which is very open to new products (trend followers)

e) A generation that is influenced easily and prioritizes the comments from people around them. A generation that thinks pride is number one.

\subsection{Lifestyle}

Lifestyle is a consumptive pattern which pictures someone's choice on how to spend time and money [14]. Lifestyle influences the thinking and consumptive patterns of a society very much in order to reach a comfortable life to enjoy. Joseph Plummer (1974) in research done 
by Susanto [15], Sathish \& Rajamohan [16] stated that lifestyle segmentation measures humans' lifestyles in terms of:

\section{a. Activities}

Activities are someone's way to spend his/her time and money on activities or hobbies he/she often does and likes. The indicator to measure activities is based on someone's activities in and out of his/her home to socialize.

b. Interests

Interests are something attracting someone to do something. Someone may be interested in a particular food, fashion, or recreation. The indicator of interests can be seen from how ones like one's job, recreation, food, and so on.

c. Opinions

Opinions are individual thoughts every consumer has. The indicator to measure someone's opinions can be seen from his/her views about the future, economics, and so on.

\subsection{Motivations}

Motivations are a condition in an individual that triggers behavior to a certain goal [17]. When talking and discussing motivations, there is one term which is called motive. The motive in psychology is derived from a Latin word "movene" which means to move. Someone's motives in doing something vary depending on the goals for doing so, for example, shopping motives. Shopping motives are generally divided into two, namely, utilitarian shopping motives and hedonic shopping motives. Both utilitarian shopping motives and hedonic shopping motives function simultaneously in purchasing decisions.

\subsubsection{Hedonic Shopping Motives}

Hedonic shopping motives are psychological needs like emotions, satisfaction, pride, and other subjective feelings. This need often appears to fulfill social and aesthetics pressures.

Hedonic shopping motives were developed by Arnolds dan Reynold with the following indicators:

- Adventure Shopping

Shopping is a challenge or a happy sensation.

- Gratification Shopping In a complex and dynamic life, some people shop to release stress. The function of shopping is reflected in pleasures.

- Value Shopping

Some people shop to find good and valuable items for themselves.

- Social Shopping I am shopping for social purposes. The concept of shopping because they can feel pleasure while shopping with others.

- Idea Shopping

Shopping gives new knowledge and experience.

\subsubsection{Utilitarian Shopping Motives}

Utilitarian shopping motives are motives that push consumers to buy products because of the objective functions and characteristics of the products [18]. According to the research [19], the indicators of utilitarian shopping motives are:

- Achievement

In shopping, the most important part is getting the item which has been targeted before. 
- Efficiency

Fun shopping is when the needed item can be bought easily and fast.

- Quality of Product

The item sold is still in good condition, intact, unbroken, and ready to find.

- Quality of Service

Sellers will observe and offer some help and do not feel bothered by inquisitive buyers.

\subsection{Purchase Intention}

Purchase or shopping intention some up when someone does an activity which happens because there is a feeling (affective) or a thought (cognitive) which orients towards the future. Some indicators which influence consumers' purchasing or shopping interests directly based on the research done by Adji, Hatane, \& Siwalankerto [20] are:

a. Transactional Interests

Someone's tendency to buy a product he/she wants.

b. Referential Interests

Someone's tendency to buy products which have been referred to by others.

c. Preferential Interests

This depicts someone who has a primary preference for certain products and can shift to other products if something happens to particular products.

d. Explorative Interests

An interest that describes someone's behavior, that is, searching for information related to the product he/she likes, and he/she searches information to support the superiority of the product. [21].

\subsection{Research Hypothesis}

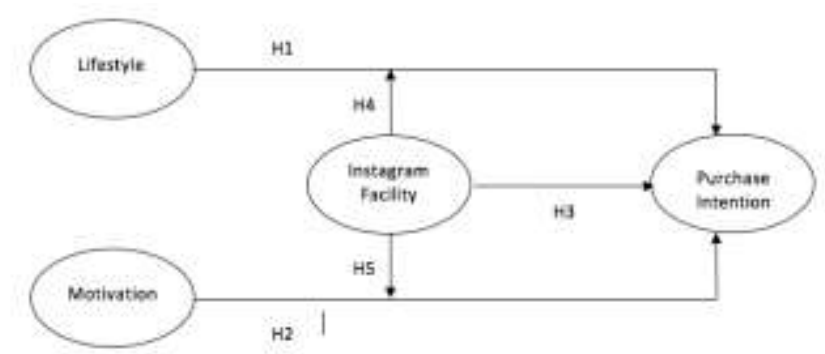

Fig. 1. Research model

H1: Lifestyles influence significantly on the intention of buying branded bags among the millennial generation.

H2: Motivations influence significantly on the intention of buying branded bags among the millennial generation.

H3: Instagram Facility influences significantly on the intention of buying branded bags among the millennial generation.

H4: Instagram Facility significantly moderates the relation between lifestyles and the intention of buying branded bags among the millennial generation directly.

H5: Instagram Facility significantly moderates the relationship between motivations and the intention of buying branded bags among the millennial generation directly. 


\section{Research Methodology}

\subsection{Research Types}

The type of research done is clausal qualitative research, where there are numbers and statistical analyses using a questionnaire as the instrument to search the cause-and-effect relation or the influence between independent and dependent variables [22].

\subsection{Population and Research Samples}

Population, according to Kuncoro is a group of complete elements, normally appears as people or interesting events that are made as research objects [23]. In this research, the population used is the millennial generation, which lives in Surabaya and is fashion consumers. The technique to obtain samples applied in this research is purposive sampling, which means that in the process of taking samples, everyone in the same population with certain criteria is given an equal chance.

The criteria and sample considerations:

1. Male and female citizens in Surabaya

2. A part of the millennial generation (aged between 18 and 35)

3. Are Instagram users

4. Have ever visited Instagram accounts which sell branded bags

\subsection{Data Analysis Techniques}

\section{Descriptive Statistics}

Mean analysis is used to know the average answer frequency each respondent gives to each question in each dimension of the research variables, while standard deviation analysis is to know the rate of data distribution.

2. PLS Analysis

Evaluation measurements in PLS-SEM are done by assessing the results of model measurements, which consist of two-equation sets, that is, Goodness-of-Fit Outer Model (measurement model) dan Goodness-of-Fit Inner Model (structural model) [24]. Outer Model consists of convergent and discriminant validity tests and reliability tests using composite reliability dan Cronbach alpha. The inner Model consists of t-statistic tests and path coefficient calculations (R-square).

3. Validity Test

The techniques used are convergent validity and discriminant validity. A statement is considered valid if the loading factor fulfills the score $\leq 0.5$, and the AVEvalue is above 0.5 , which means the valid and true indicator to explain the variables which will be measured.

4. Reliability Test

The techniques used in this research are Cronbach's alpha test dan composite reliability. The questions in the questionnaire are stated as reliable if the scores are over 0.7, which means that the indicators are reliable and constant from time to time.

5. R-square

$\mathrm{R}$-square measures the variety rate of independent variables. The higher the $\mathrm{R}$-square rate is, the more capable it is to predict the model (predictive relevance). 
6. $\mathrm{t}$-Test

$\mathrm{t}$-Test is used to know the significance of a relation among variables. If the value of $\mathrm{t}$ statistics $>1.96$, a relation is stated as significant.

\section{Data Analysis and Discussion}

The questionnaires were distributed using a Google link to 165 respondents living in Surabaya. From the 165 respondents, $75.8 \%$ were women, $73.3 \%$ were 18 to 23 years old, $60.0 \%$ were school or university students, and $61.8 \%$ bought fashion products on Instagram.

\subsection{Goodness-of-Fit Outer Model}

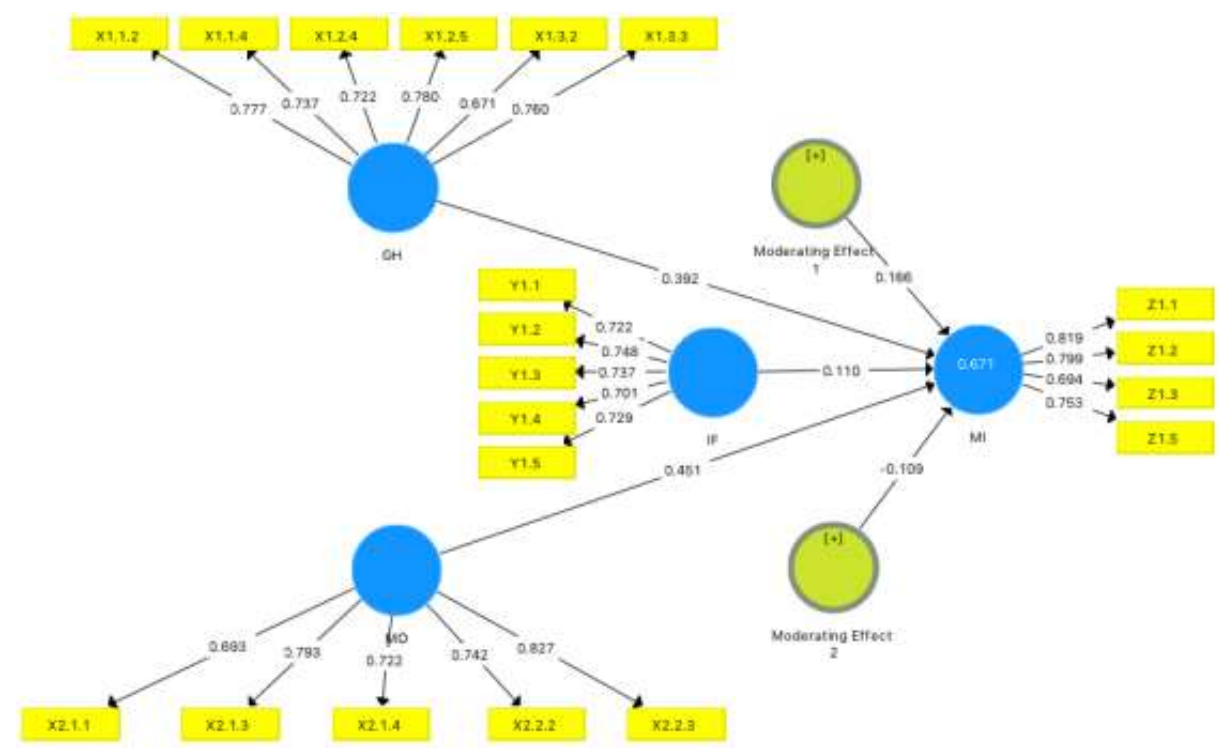

Fig. 2. Outer model

Based on the calculation using the smartPLS program, it was found out that all indicators had more than 0.5 loading factors, which meant that the indicator had a big contribution in explaining the variables.

Table 1. Cross loadings

\begin{tabular}{lcccccc}
\hline & GH & IF & MI & MO & Moderating Effect 1 & Moderating Effect 2 \\
\hline GH & $\mathbf{0 . 7 4 2}$ & & & & & \\
IF & 0.428 & $\mathbf{0 . 7 2 7}$ & & & & \\
MI & 0.729 & 0.436 & $\mathbf{0 . 7 6 8}$ & & & \\
MO & 0.707 & 0.393 & 0.753 & $\mathbf{0 . 7 5 7}$ & & \\
Moderating & -0.293 & -0.259 & -0.156 & -0.225 & 1.000 & \\
Effect 1 & & & & & & 1.000 \\
Moderating & -0.195 & -0.217 & -0.186 & -0.176 & 0.727 & \\
Effect 1 & & & & & & \\
\hline
\end{tabular}


Through the above table, it can be concluded that the AVE value of each variable was more than 0.5 , and the correlation value was bigger than the other construct correlations, so it can be said that the indicators could explain their latent variables very well.

\subsection{Goodness-of-Fit Inner Model}

The value of R-Square in the purchase interest variable was 0.671 . this value means that the value of the purchase intention variable, as much as $67.1 \%$, could be explained using independent variables (Lifestyle, Purchase Intention, and Instagram Facility), while as much as $32.9 \%$ could be explained using other uninspected factors.

Table 2. Path analysis

\begin{tabular}{lcccc}
\hline & $\begin{array}{c}\text { Original Sample } \\
(\mathrm{O})\end{array}$ & $\begin{array}{c}\text { Sample Mean } \\
(\mathrm{M})\end{array}$ & $\begin{array}{c}\text { Standard Deviation } \\
(\text { STDEV })\end{array}$ & $\begin{array}{c}\text { T Statistics } \\
(\mid \mathrm{O} / \mathrm{STDEC})\end{array}$ \\
\hline $\mathrm{GH} \rightarrow \mathrm{MI}$ & 0.392 & 0.409 & 0.083 & 4.751 \\
$\mathrm{IF} \rightarrow \mathrm{MI}$ & 0.110 & 0.134 & 0.060 & 1.830 \\
$\mathrm{MO} \rightarrow$ MI & 0.451 & 0.420 & 0.099 & 4.547 \\
Moderating Effect 1 $(\mathrm{GH}) \rightarrow$ & 0.166 & 0.144 & 0.127 & 1.300 \\
$\mathrm{MI}$ & & & & \\
Moderating Effect 2 $(\mathrm{MO}) \rightarrow$ & -0.109 & -0.085 & 0.107 & 1.019 \\
MI & & & & \\
\hline
\end{tabular}

The calculation result of t-statistic shows that there was a significant relation between lifestyles and motivations to purchase intention that is t-statistic $>1.96$. Meanwhile, there was no significant relation between the Instagram facility and either purchase intention or moderating connection. Therefore, the results of the hypothetical test are:

Table 3. Hypothesis

\begin{tabular}{clllc}
\hline Hypothesis & \multicolumn{1}{c}{ Variable 1 } & \multicolumn{1}{c}{ Variable 2 } & Moderating & Result \\
\hline H1 & Lifestyle & Purchase Intention & & V \\
H2 & Motivation & Purchase Intention & & V \\
H3 & Instagram Facility & Purchase Intention & & X \\
H4 & Lifestyle & Purchase Intention & Instagram Facility & X \\
H5 & Motivation & Purchase Intention & Instagram Facility & X \\
\hline
\end{tabular}

\section{Discussion}

\subsection{Lifestyle $\rightarrow$ Purchase Intention}

The calculation of t-statistic between lifestyles and purchase intention, which exceeded 1.96, that is, 4.751, proved that there was high significance. The higher someone's lifestyle is, the more interest that person has in buying branded bags. Besides, when connecting the 
characteristics of the respondents who fall under the millennial generation category, lifestyles have a very high influence on purchase intention. The lifestyles of the generation, which are reflected through the interests in luxurious products, prove the existence of high purchase intention.

This analysis was also supported by research previously done by Amatulli \& Guido [25] that lifestyles could influence purchase intention. Their research was about factors that determined someone's luxurious shopping activity in Italy. From the research, it was found that one of the factors to make someone have the intention to buy luxurious fashion items was the luxurious lifestyle of most citizens.

\subsection{Motivation $\rightarrow$ Purchase Intention}

There was also quite a high value in the motivation and purchase intention variables, that is, t-statistic as high as 4.547. This shows that there was a significant relation between motivations and purchase intentions.

This analysis was supported by earlier research done by Sarah Giovanini to a small number of the millennial generation in the United States. Her research found that there was an influence of self-motivation on the purchase intention of luxurious goods where someone was motivated to buy because of having high self-esteem or pride [26].

\subsection{Instagram Facility $\rightarrow$ Purchase Intention}

The research results show that there was an insignificant influence between Instagram Facility (facilities in Instagram) and purchase intentions. It can be found out from the value of the t-statistic of $1.830(>1.96)$, which means that the relation between the two was insignificant.

This was caused by the phenomenon of fake branded bags being sold on Instagram. This deceiving activity made use of social media facilities, like hashtags in Instagram Facility to convince interested buyers that the items sold were authentic. It can be concluded that hashtags did not become a factor that influenced purchase intentions.

\subsection{Lifestyle $\rightarrow$ Instagram Facility $\rightarrow$ Purchase Intention}

The value of the t-statistic calculation was quite low, that is, $1.300(<1.96)$, which means that there was no significant moderating relation. It can be concluded that not all respondents on Instagram shopped, and not all respondents had the same shopping hobby. For example, some may use Instagram to increase their connections and add business ideas.

\subsection{Motivation $\rightarrow$ Instagram Facility $\rightarrow$ Purchase Intention}

The value of the t-statistic calculation was quite low, that is, $1.019(<1.96)$, which means that there was no significant moderating relation. When someone had a motivation to buy his/her targeted product, he/she planned beforehand, such as finding the account to buy the product of his/her target. Hence, facilities in Instagram did not increase or even improve his/her motivation to have purchase intentions because everything had been planned.

\section{Conclusion}


Lifestyles had a significant influence on Purchase Intentions. This showed that someone's lifestyle would influence his/her interest in buying branded bags. The Motivation variable had a significant influence on Purchase Intentions. This was shown through someone's motivation to feel happiness and satisfaction after getting his/her targeted branded bag.

The Instagram Facility variable did not have a significant influence on Purchase Intentions. It can be concluded that not all people used facilities on Instagram to shop. The Instagram facility variable did not significantly moderate either lifestyles or motivations to purchase intentions. The main cause Instagram facility was not considered when buying branded bags was the number of incidents that influenced people to think twice before making any purchase. An example of the incident was the existence of fake Instagram accounts selling branded bags.

\section{Suggestions}

This research is hoped to give more knowledge of the significant relations between lifestyles and purchase interests as well as motivations and purchase intentions. This research can also give ideas and inputs to online business doers to improve their marketing strategies because they have to face different characteristics of the millennial generation.

Since this is quantitative research, it is hoped that the researcher can continue doing the research with a wider range of respondents instead of being limited to people in Surabaya. The research can also be expanded to different branded fashion products, like shoes and clothes, so as to acquire a broader perspective.

\section{References}

[1] Atmoko, D.: Instagram Handbook. Jakarta: Media Kita (2012)

[2] Indonesia Asosiasi Penyelenggara Jasa Internet, "Profil Pengguna Internet Indonesia 2014," (2015)

[3] Furlow, N.: "Find us on Facebook: How Cause Marketing has Embraced Social Media," J. Mark. Dev. Compet., pp. 61-64 (2012)

[4] Valentine, D. B., and Powers, T. L.: "Generation Y values and lifestyle segments," J. Consum. Mark., vol. 30, no. 7, pp. 597-606 (2013)

[5] Hiremart, B. M., and Gudasi, C. R.: "FDI in Retail Boon and Bane," ASM's Int. E-Journal “Ongoing Res. Manag. IT,” (2015)

[6] Kaplan and, A. M., and Haenlein, M.: "Users of the world, unite! The challenges and opportunities of social media," Bus. Horiz., p. 61 (2010)

[7] Budiargo, D.: Berkomunikasi Ala Net Generation. Jakarta: PT Elex Media Komputindo Kompas Gramedia (2015)

[8] Lea, S.: Instagram: Explore Your Business Today! Lexington: Haven Publishing Group, 2013.

[9] Instagram Business, "Instagram TV," (2019)

[10] Miles, J. G.: Instagram Power. New York: Mc Graw Hill Education (2013)

[11] Kapferer, J. N., and Bastien, V.: The Luxury Strategy: Break the Rules of Marketing to Build Luxury Brands. London: Kogan Page (2009)

[12] Cholifaturrosida, et al.: "Pengaruh Hedonic dan Utilitarian Motivation Terhadap Behavioral Intention Pada Pemilihan Tas Mewah,” J. Bus. Adm., vol. 55, no. 02 (2018)

[13] Noble, S. M., Haytko, D. L., and Phillips, J.: "What drives college-age Generation Y consumers?," J. Bus. Res., vol. 62, no. 6, pp. 617-628 (2009)

[14] Solomon, M. R.: Consumer Behavior: Buying, Having, and Being. New Jersey: Prentice Hall, (2009) 
[15] Susanto, A. S.: "Metode Penelitian Kuantitiatif Kualitatif dan R\&D,” JIBEKA J (2011)

[16] Sathish, S. and Rajamohan, A.: "Consumer behaviour and lifestyle marketing," Int. J. Mark. Financ. Serv. Manag. Res., vol. 1, no. 10, pp. 152-166 (2012)

[17] Schiffman, L. G., Hansen, H. and Kanuk, L.: Consumer Behavior: A European Outlook. New York: Financial Times Prentice Hall (2011)

[18] Setiadi, N.: Perilaku Konsumen Konsep dan Implikasi untuk Strategi dan Penelitian Pemasaran. Jakarta: Kencana Prenada Group (2008)

[19] Babin, B. J., Darden, W. R. and Griffin, M. "Work and/or Fun: Measuring Hedonic and Utilitarian Shopping Value,” J. Consum. Res., vol. 20, no. 4, pp. 644-656 (1994)

[20] Adji, J., Hatane, D., and Siwalankerto, J.: "Pengaruh Satisfaction dan Trust Terhadao Minat Beli Konsumen,” J. Manaj. Pemasar. Petra, vol. 2, no. 1, pp. 1-10 (2014)

[21] Ferdinand, A.: Pengembangan Minat Beli Merek Ekstensi. Semarang: Badan Penerbit Universitas Diponegoro (2002)

[22] Sugiyono, P. D.: Metode Penelitian Kuantitiatif Kualitatif dan R\&D. Bandung: Alfabeta (2011)

[23] Kuncoro, M. : Metode Riset Untuk Bisis \& Ekonomi. Jakarta: Erlangga (2003)

[24] Ghozali, I.: Structural Equation Modeling: Metode Alternatif Dengan Partial Least Square (PLS). Semarang: Universitas Diponegoro Publisher (2008)

[25] Amatulli, C., and Guido, G.: "Determinants of purchasing intention for fashion luxury goods in the Italian market: A laddering approach,” J. Fash. Mark. Manag., vol. 15, no. 1, pp. 123-136 (2011)

[26] Giovannini, S., Xu, Y., and Thomas, J.: "Luxury fashion consumption and Generation Y consumers,” J. Fash. Mark. Manag. An Int. J., vol. 19, no. 1, pp. 22-40 (2015) 